\title{
JUAL BELI E-COMMERCE DALAM PERSFEKTIF HUKUM ISLAM
}

\author{
Ardiana Hidayah \\ Fakultas Hukum Universitas Palembang \\ E-mail: ardyanah@yahoo.co.id
}

\begin{abstract}
Buying and selling is one type of mu'amalah regulated in Islamic Law. Based on its form, e-commerce is a model of buying and selling transactions. The concept of e-commerce buying and selling leads to engagement between the parties to provide an achievement. Based on Sunnah Fiqh, buying and selling is the exchange of property (whatever its form) is done voluntarily or the process of transferring property rights to other people with compensation or certain rewards. According to Islamic Law, e-commerce buying and selling is permissible, if it is in accordance with the rules of fiqh in the basic principles of muamalah transaction and its requirements as long as it is not prohibited by sharia or contrary to the argument
\end{abstract}

Keywords: buying and selling e-commerce

\begin{abstract}
Abstrak
Jual-beli merupakan salah satu jenis mu'amalah yang diatur dalam Hukum Islam. Berdasarkan bentuknya e-commerce pada dasarnya merupakan model transaksi jual-beli. Konsep perdagangan jual beli e-commerce menimbulkan perikatan antara para pihak untuk memberikan suatu prestasi. Berdasarkan Fiqih Sunnah, jual beli adalah tukar menukar harta (apapun bentuknya) yang dilakukan secara sukarela atau proses mengalihkan hak milik harta pada orang lain dengan kompensasi atau imbalan tertentu. Pandangan Hukum Islam pada jual beli e-commerce adalah boleh, jika sesuai dengan kaidah fikih dalam prinsip dasar transaksi muamalah dan persyaratannya selama tidak dilarang oleh syariah atau bertentangan dengan dalil.
\end{abstract}

Kata Kunci: jual beli e-commerce

\section{Pendahuluan}

Perkembangan teknologi dibidang perdagangan adalah perdagangan secara elektronik. Dimana antara pihak penjual dan pembeli tidak bertemu secara langsung, melainkan hanya melalui jaringan internet. Perdagangan secara elektronik dilakukan pada transaksi secara elektronik atau e-commerce yang disebut juga jual beli online.

Pada Konsep perdagangan jual beli e-commerce menimbulkan perikatan antara para pihak untuk memberikan suatu prestasi. Implikasi dari perikatan itu adalah timbulnya hak dan kewajiban yang harus dipenuhi oleh para pihak yang terlibat. ${ }^{1}$ Dalam jual beli yang menimbulkan adanya perikatan menyebabkan adanya hubungan para pihak, yakni pihak yang satu berhak

\footnotetext{
${ }^{1}$ Azhar Muttaqin, Transaksi E-Commerce dalam Tinjauan Hukum Jual Beli Islam, ULUMUDDIN, Volume VI, Tahun IV, Januari - Juni 2010, hlm.460
}

prestasi dan pihak lainnya wajib memenuhi prestasi, begitu juga sebaliknya. $^{2}$

Pada setiap jual beli sekurang-kurangnya terdapat dua pihak, yaitu pihak penjual yang berkewajiban menyerahkan barang objek jual beli dan pihak pembeli yang berkewajiban membayar harga pembelian. Dalam hubungan dengan kewajiban pihak penjual dalam suatu jual beli, disamping kewajiban penjual untuk menyerahkan barang, pihak penjual dibebankan kewajiban menanggung. Menanggung tersebut adalah menjamin bahwa penguasaan benda aman dan tidak terdapat cacat tersembunyi. $^{3}$

\footnotetext{
${ }^{2}$ Elsi Kartika Sari dan Advendi Simanunsong, Hukum dalam Ekonomi, Jakarta: PT Gramedia Widiasarana Indonesia, 2008, hlm. 28

${ }^{3}$ Munir Fuady, Pengantar Hukum Bisnis, Menata Bisnis Modern di Era Global, Bandung: PT Citra Aditya Bakti, 2008, hlm. 25-26
}

Volume 17 Nomor 1. Bulan Januari 2019 
Pandangan Hukum Islam pada jual-beli merupakan salah satu jenis mu'amalah yang diatur dalam Islam. Melihat bentuknya e-commerce pada dasarnya merupakan model transaksi jual-beli juga, akan tetapi hal tersebut dikategorikan sebagai jual beli modern karena mengimplikasikan inovasi teknologi. Secara umum perdagangan secara Islam menjelaskan adanya transaksi yang bersifat fisik, dengan menghadirkan benda tersebut pada saat transaksi jual beli, sedangkan e-commerce tidak seperti itu, sehingga e-commerce merupakan model perjanjian jual beli dengan karakteristik tersendiri yang melakukan kegiatan transaksi pada jangkauan lokal maupun global. Oleh karena itu, permasalahan dalam tulisan ini adalah bagaimana pandangan Hukum Islam pada jual beli e-commerce.

\section{Pembahasan}

\section{A. Tinjauan tentang E-Commerce}

Kegiatan jual beli di era digital yang paling popular adalah e-commerce. E-commerce merupakan jenis bisnis yang dijalankan antara pelaku bisnis dengan konsumen secara online, e-commerce dapat terjadi antara organisasi bisnis dengan konsumen. ${ }^{4}$

E-Commerce satu rangkaian yang dinamis pada teknologi, aplikasi dan proses bisnis yang menghubungkan perusahaan, konsumen dan komunitas tertentu melalui transaksi elektronik dan perdagangan barang, pelayanan dan informasi yang dilakukan secara elektronik.

Berdasarkan ketentuan Pasal 1 angka 10 Undang-undang Tentang Informasi dan Transaksi Elektronik (UU ITE), disebutkan bahwa transaksi elektronik adalah perbuatan hukum yang dilakukan dengan menggunakan komputer, jaringan komputer atau media elektronik lainnya. Transaksi jual beli

\footnotetext{
4 Jamhurul dalam Muhammad Nizar, Pendekatan Komprehensif E-Commerce Prespektif Syariah, Perisai, Vol 2 (1), April 2018, Journal Homepage: http://ojs.umsida.ac.id/index.php/perisai, hlm. 77
}

secara elektronik merupakan salah satu perwujudan ketentuan di atas.

Transaksi jual beli secara elektronik, sama halnya dengan transaksi jual beli biasa yang dilakukan di dunia nyata, dilakukan oleh para pihak yang terkait, walaupun dalam jual beli secara elektronik ini pihak-pihaknya tidak bertemu secara langsung satu sama lain, tetapi berhubungan melalui internet. Dalam transaksi jual beli secara elektronik, pihak-pihak yang terkait antara lain ${ }^{5}$

1. Penjual atau merchant atau pengusaha yang menawarkan sebuah produk melalui internet sebagai pelaku usaha;

2. Pembeli atau konsumen yaitu setiap orang yang tidak dilarang oleh undang-undang, melakukan transaksi jual beli produk yang ditawarkan oleh penjual/ pelaku usaha/ merchant.

3. Bank sebagai pihak penyalur dana dari pembeli atau konsumen kepada penjual atau pelaku usaha/merchant.

4. Provider sebagai penyedia jasa layanan akses internet.

Pada dasarnya pihak-pihak dalam jual beli secara elektronik tersebut diatas, masing-masing memiliki hak dan kewajiban. Penjual/pelaku usaha/merchant merupakan pihak yang menawarkan produk melalui internet, oleh karena itu, seorang penjual wajib memberikan informasi secara benar dan jujur atas produk yang ditawarkannya kepada pembeli atau konsumen.

Perdagangan Elektronik (E-Commerce = electronic commerce) adalah bagian dari e-lifestyle yang memungkinkan transaksi jual beli dilakukan secara online dari sudut
5 Edmon Makarim, Kompilasi Hukum Telematika. Jakarta: PT.Gravindo Persada, 2000 dalam Azhar Muttaqin, Transaksi E-Commerce dalam Tinjauan Hukum Jual Beli Islam, ULUMUDDIN, Volume VI, Tahun IV, Januari - Juni 2010, hlm. 461 
tempat mana pun. ${ }^{6}$ E-Commerce juga sebagai suatu proses berbisnis dengan menggunakan teknologi elektronik yang menghubungkan antara perusahaan, konsumen dan masyarakat dalam bentuk transaksi elektronik dan pertukaran/penjualan barang, servis, dan informasi secara elektronik.

Dalam banyak kasus, sebuah perusahaan e-commerce bisa bertahan tidak hanya mengandalkan kekuatan produk saja, tapi dengan adanya tim manajemen yang handal, pengiriman yang tepat waktu, pelayanan yang bagus, struktur organisasi bisnis yang baik, jaringan infrastruktur dan keamanan, desain situs web yang bagus, beberapa faktor yang termasuk:

1. Menyediakan harga kompetitif

2. Menyediakan jasa pembelian yang tanggap, cepat, dan ramah.

3. Menyediakan informasi barang dan jasa yang lengkap dan jelas.

4. Menyediakan banyak bonus seperti kupon, penawaran istimewa, dan diskon.

5. Memberikan perhatian khusus seperti usulan pembelian.

6. Menyediakan rasa komunitas untuk berdiskusi, masukan dari pelanggan, dan lain-lain.

7. Mempermudah kegiatan perdagangan

E-Commerce atau Electronic

Commerce adalah metodologi bisnis modern yang membahas kebutuhan organisasi bisnis, vendor dan pelanggan untuk mengurangi biaya dan meningkatkan kualitas barang dan jasa sekaligus mempercepat waktu pengiriman. E-commerce mengacu pada pertukaran informasi bisnis tanpa kertas dengan cara berikut.

1. Electronic Data Interchange (EDI)

2. Electronic Mail (e-mail)

3. Electronic Bulletin Boards

4. Electronic Fund Transfer (EFT)

5. Other Network-based technologies

6 Muchlisin Riadi, Perdagangan Elektronik (E-Commerce), https://www.kajianpustaka.com/2013/04/ perdagangan- elektronik- e-commerce.html,

\section{Perbandingan E-Commerce dengan Traditional Commerce}

Berikut adalah perbandingan antara e-commerce yang lebih dikenal dengan penjulan online dengan Traditional Commerce atau dikenal dengan penjalan langsung atau ofline.

\begin{tabular}{|c|c|}
\hline E-Commerce (Online) & Tradisional (Ofline) \\
\hline $\begin{array}{l}\text { Berbagi informasi } \\
\text { dibuat mudah melalui } \\
\text { jalur komunikasi } \\
\text { elektronik yang } \\
\text { membuat } \\
\text { ketergantungan kecil } \\
\text { pada pertukaran } \\
\text { informasi orang ke } \\
\text { orang. }\end{array}$ & $\begin{array}{l}\text { Ketergantungan } \\
\text { berat pada } \\
\text { pertukaran informasi } \\
\text { dari orang ke orang }\end{array}$ \\
\hline $\begin{array}{l}\text { Komunikasi atau } \\
\text { transaksi bisa dilakukan } \\
\text { secara asinkron. Sistem } \\
\text { elektronik secara } \\
\text { otomatis menangani } \\
\text { kapan harus } \\
\text { menyampaikan } \\
\text { komunikasi kepada } \\
\text { orang yang dibutuhkan } \\
\text { atau melakukan } \\
\text { transaksi. }\end{array}$ & $\begin{array}{l}\text { Komunikasi atau } \\
\text { transaksi dilakukan } \\
\text { secara sinkron. } \\
\text { Intervensi manual } \\
\text { diperlukan untuk } \\
\text { setiap komunikasi } \\
\text { atau transaksi. }\end{array}$ \\
\hline $\begin{array}{l}\text { Tidak ada campur } \\
\text { tangan manusia. }\end{array}$ & $\begin{array}{l}\text { Komunikasi bisnis } \\
\text { bergantung pada } \\
\text { keterampilan } \\
\text { penjualnya } \\
\end{array}$ \\
\hline $\begin{array}{l}\text { Website E-Commerce } \\
\text { menyediakan platform } \\
\text { kepada pengguna di } \\
\text { mana informasi tersedia } \\
\text { di satu tempat. }\end{array}$ & $\begin{array}{l}\text { Tidak tersedianya } \\
\text { platform yang } \\
\text { seragam karena } \\
\text { perdagangan } \\
\text { tradisional sangat } \\
\text { bergantung pada } \\
\text { komunikasi pribadi. }\end{array}$ \\
\hline
\end{tabular}

Apabila dibandingkan dengan proses perdagangan tradisional (manual), e-commerce memiliki beberapa keunggulan. Bagi Konsumen: harga lebih murah, belanja cukup pada satu tempat. Bagi Pengelola bisnis: efisiensi, tanpa kesalahan, tepat waktu. Bagi Manajemen: peningkatan pendapatan, loyalitas pelanggan. Dengan keuntungan-keuntungan tersebut yang menjadikan e-commerce menjadi alternatif perluasan bisnis bagi para 
pelaku usaha dan sudah menjadi bagian dari gaya hidup manusia modern di era teknologi sekarang ini.

\section{B. Jual Beli Menurut Hukum Islam}

Secara etimologi, Al Bay'u atau jual beli memiliki arti mengambil dan memberikan sesuatu. Hal ini merupakan turunan dari Al Bara sebagaimana orang Arab senantiasa mengulurkan depa ketika melangsungkan akad jual beli agar saling menepukkan tagan. Hal ini sebagai tanda bahwa akad jual beli tersebut sudah terlaksana dan akhirnya mereka saling bertukar uang atau barang. Sedangkan secara terminiologi, jual beli memiliki arti transaksi tuka menukar barang atau uang yang berakibat pada beralihnya hak milik barang atau uang. Prosesnya dilaksanakan dengan akad, baik secara perbuatan maupun ucapan lisan. Hal ini dijelaskan dalam kitab Tauhidul Ahkam atau Kitab Hukum Tauhid, 4-211. ${ }^{7}$

Berdasarkan Fiqih Sunnah, jual beli adalah tukar menukar harta (apapun bentuknya) yang dilakukan mau sama mau atau sukarela atau proses mengalihkan hak milik harta pada orang lain dengan kompensasi atau imbalan tertentu. Menurut Fiqih Sunnah, hal ini boleh dilakukan asalkan masih dalam koridor syariat. Seperti harta dan barang yang dijual belikan adalah halal, bukan benda haram, atau asalnya dari jalan yang haram.

Secara umum, Islam telah mengatur segala aspek kehidupan manusia hingga pada permasalahan ekonomi, khususnya masalah jual beli. Islam sebagai agama yang Rahmatan Lil Alamin, tentu saja mengatur hal jual beli dalam rangka memberikan kemaslahatan atau tidak terjadi kemudharatan atau dampak buruk dari transaksi yang dilakukan. Manusia adalah mahluk yang berakal yang juga memiliki hawa nafsu, akhirnya aturan

\footnotetext{
7 Jual Beli Menurut Islam - Aturan dan Syaratnya, https://dalamislam.com/hukum-islam/ekonomi

harus ada dan diterapkan agar hawa nafsu manusia tidak mengakibatkan ketidakadilan. $^{8}$

Persyaratan dalam Jual Beli Menurut Hukum Islam adalah sebagai berikut: ${ }^{9}$

\section{Persyaratan yang berkaitan dengan} pelaku praktek jual beli, baik penjual maupun pembeli, yaitu: Hendaknya kedua belah pihak melakukan jual beli dengan ridha dan sukarela, tanpa ada paksaan. Allah SWT berfirman dalam Quran Surat An-Nissa ayat 29 yang artinya: “... janganlah kalian saling memakan harta sesamamu dengan jalan yang batil, kecuali dengan jalan perniagaan yang timbul dari kerelaan di antara kalian..." (QS. An-Nisaa': 29).

Kedua belah pihak berkompeten dalam melakukan praktek jual beli, yakni dia adalah seorang mukallaf dan rasyid (memiliki kemampuan dalam mengatur uang), sehingga tidak sah transaksi yang dilakukan oleh anak kecil yang tidak cakap, orang gila atau orang yang dipaksa (Fikih Ekonomi Keuangan Islam, hal. 92). Hal ini merupakan salah satu bukti keadilan agama ini yang berupaya melindungi hak milik manusia dari kezaliman, karena seseorang yang gila, safiih (tidak cakap dalam bertransaksi) atau orang yang dipaksa, tidak mampu untuk membedakan transaksi mana yang baik dan buruk bagi dirinya sehingga dirinya rentan dirugikan dalam transaksi yang dilakukannya.

2. Persyaratan yang berkaitan dengan objek/barang yang diperjualbelikan, syarat-syaratnya yaitu: ${ }^{10}$

a. Objek jual beli (baik berupa barang jualan atau harganya/uang) merupakan barang yang suci dan bermanfaat, bukan barang najis atau barang yang haram, karena barang

\footnotetext{
8 Ibid

9 Muhammad Abduh Tuasikal, Jual Beli dan

Syarat-Syaratnya, https://muslim.or.id/222-jual-beli-dansyarat-syaratnya.html ${ }^{10}$ Ibid
} 
yang secara dzatnya haram terlarang untuk diperjualbelikan.

b. Objek jual beli merupakan hak milik penuh, seseorang bisa menjual barang yang bukan miliknya apabila mendapat izin dari pemilik barang. Rasulullah shallallahu 'alaihi wa sallam bersabda, bahwa "Janganlah engkau menjual barang yang bukan milikmu." (HR. Abu Dawud 3503, Tirmidzi 1232, An Nasaa'i VII/289, Ibnu Majah 2187, Ahmad III/402 dan 434; dishahihkan Syaikh Salim bin 'Ied Al Hilaly).

Seseorang diperbolehkan melakukan transaksi terhadap barang yang bukan miliknya dengan syarat pemilik memberi izin atau rida terhadap apa yang dilakukannya, karena yang menjadi tolok ukur dalam perkara muamalah adalah rida pemilik. (Lihat Fiqh wa Fatawal Buyu' hal. 24). Hal ini ditunjukkan oleh persetujuan Nabi shallallahu 'alaihi wa sallam terhadap perbuatan Urwah tatkala beliau memerintahkannya untuk membeli kambing buat beliau. (HR. Bukhari Bab 28 nomor 3642).

Objek jual beli dapat diserahterimakan, sehingga tidak sah menjual burung yang terbang di udara, menjual unta atau sejenisnya yang kabur dari kandang dan semisalnya. Transaksi yang mengandung objek jual beli seperti ini diharamkan karena mengandung gharar (spekulasi) dan menjual barang yang tidak dapat diserahkan.

Objek jual beli dan jumlah pembayarannya diketahui secara jelas oleh kedua belah pihak sehingga terhindar dari gharar. Abu Hurairah berkata: "Rasulullah shallallahu 'alaihi wa sallam melarang jual beli hashaath (jual beli dengan menggunakan kerikil yang dilemparkan untuk menentukan barang yang akan dijual) dan jual beli gharar." (HR. Muslim: 1513)

Selain itu, tidak diperkenankan seseorang menyembunyikan cacat/aib suatu barang ketika melakukan jual beli. Rasulullah shallallahu 'alaihi wa sallam bersabda yang artinya sebagai berikut: "Seorang muslim adalah saudara bagi muslim yang lain. Tidak halal bagi seorang muslim menjual barang dagangan yang memiliki cacat kepada saudaranya sesama muslim, melainkan ia harus menjelaskan cacat itu kepadanya" (HR. Ibnu Majah nomor 2246, Ahmad IV/158, Hakim II/8, Baihaqi V/320; dishahihkan Syaikh Salim bin 'Ied Al Hilali).

Rasulullah shallallahu 'alaihi wa sallam juga bersabda: "Barang siapa yang berlaku curang terhadap kami, maka ia bukan dari golongan kami. Perbuatan makar dan tipu daya tempatnya di neraka" (HR. Ibnu Hibban 567, Thabrani dalam Mu'jamul Kabiir 10234, Abu Nu'aim dalam Al Hilyah IV/189; dihasankan Syaikh Salim Al Hilaly)

Berikut adalah syarat-syarat jual beli menurut islam yang perlu diperhatikan umat islam, agar jual beli terlaksana dengan adil dan seimbang. Adapun penjelasannya sebagai berikut: ${ }^{11}$

\section{Transaksi di Lakukan dengan Ridha dan Sukarela}

"Janganlah kalian saling memakan harta sesamamu dengan jalan yang batil, kecuali dengan jalan perniagaan yang timbul dari kerelaan di antara kalian..." (QS. An-Nisaa: 29). Ayat ini diperjelas bahwa kedua belah pihak harus berkompeten untuk melakukan transaksi jual beli. Mereka adalah orang orang yang

\footnotetext{
${ }^{11}$ Jual Beli Menurut Islam - Aturan dan Syaratnya, https://dalamislam.com/hukum-islam/ekonomi

/jual-beli-menurut-islam
} 
paham mengenai jual beli, mampu menghitung atau mengatur uang, dan dilakukan dengan kesadaran. Anak kecil yang tidak pandai atau belum mengetahui masalah jual beli maka lebih baik orang tuanya yang mengatur. Orang gila tentu saja tidak boleh dan dipaksa untuk membeli. Transaksi jual beli tidak boleh dilakukan secara terpaksa, namun karena kebutuhan dan sukarela antara dua belah pihak. Jika tidak maka salah satu pihak akan dirugikan.

\section{Barang Bukan Milik Orang Lain}

"Janganlah engkau menjual barang yang bukan milikmu.” (HR. Abu Dawud)

Dari hadist di atas dijelaskan bahwa barang yang dijual bukanlah milik orang lain. Untuk itu harus pasti, miliknya adalah milik pribadi, atau harta pemberian tidak masalah asalkan berasal dari sumber yang berkah dan halal, jelas status kepemilikannya.

\section{Larangan Jual Beli Hasaath}

"Rasulullah shallallahu 'alaihi wa sallam melarang jual beli hashaath (jual beli dengan menggunakan kerikil yang dilemparkan untuk menentukan barang yang akan dijual) dan jual beli gharar." (HR. Muslim). Hal tersebut menjelaskan bahwa dilarang jual beli dengan kerikil yang dilempar untuk menentukan barang. Hal ini berarti mereka tidak bisa memilih, memilah barang yang sesuai keinginan dan sesuai kualitas barangnya.

\section{Menjelaskan Cacat Barang}

"Seorang muslim adalah saudara bagi muslim yang lain. Tidak halal bagi seorang muslim menjual barang dagangan yang memiliki cacat kepada saudaranya sesama muslim, melainkan ia harus menjelaskan cacat itu kepadanya" (HR. Ibnu Majah)

Jika terdapat cacat maka penjual harus memberikan informasi mengenai cacat barang-nya, tidak boleh ditutupi. Hal ini tentu akan mengecewakan dan menipu pembeli. Sebagaimana disampaikan oleh Rasulullah dalam hadist berikut, "Barang siapa yang berlaku curang terhadap kami, maka ia bukan dari golongan kami. Perbuatan makar dan tipu daya tempatnya di neraka” (HR. Ibnu Hibban)
Jual beli berdasarkan hukum Islam termasuk dalam muamalah yang pelaksanaanya berpedoman pada prinsip-prinsip hukum Islam. Prinsip hukum Islam merupakan titik tolak pelaksanaan ketetapan-ketetapan Allah yang berkaitan dengan mukallaf, baik yang berbentuk perintah, larangan maupun pilihan-pilihan. Prinsip yang paling utama adalah ketauhidan, keadilan dan kemanusiaan. ${ }^{12}$

Prinsip-prinsip Hukum Islam yang dijadikan landasan ideal dalam hukum Islam yaitu: ${ }^{13}$

1. Prinsip Tauhidullah, bahwa semua paradigma berpikir yang digunakan untuk menggali kandungan ajaran Islam yang termuat dalam Al-Quran dan Al-Hadits, dalam konteks ritual maupun sosial, harus bertitik tolak dari nilai-nilai ketauhidan, yakni tentang segala yang ada dan yang mungkin ada, bahkan yang mustahil ada adalah diciptkan oleh Allah SWT.

2. Prinsip Insaniyah, prinsip kemanusiaan, bahwa produk akal manusia yang dijadikan yang dijadikan rujukan dalam perilaku sosial maupun sistem budaya harus bertitik tolak dari nilai-nilai kemanusiaan, memuliakan manusia dan memberikan manfaat serta menghilangkan kemudaratan bagi manusia.

3. Prinsip Tasamuh, prinsip toleransi, sebagai titik tolak pengamalan hukum Islam. Karena cara berpikir manusia yang berbeda-beda, satu sama lain harus saling menghargai dan mengakui bahwa kebenaran hasil pemikiran manusia bersifat relatif.

4. Prinsip Ta'awun, tolong menolong, sebagai titik tolak kehidupan manusia sebagai makhluk sosial yang saling membutuhkan.

5. Prinsip Silaturahmi Baina An-Nas, sebagai titik tolak bahwa setiap individu dengan individu lainnya akan melakukan interaksi, karena manusia adalah human

\footnotetext{
12 Beni Ahmad Saebani, Filsafat Hukum Islam, Bandung Pustaka Setia, 2008, hlm. 233

13 Juhaya S. Pradja, Filsafat Hukum Islam, Bandung: Yayasan Piara, 1997 dalam Beni Ahmad Saebani, Ibid, hlm. 234-235
} 
relation yang secara fitrahnya menjadikan silaturahmi sebagai embrio terciptanya masyarakat.

6. Prinsip Keadilan atau Al-Mizan (keseimbangan) antara hak dan kewajiban. Sebagai titik tolak kesadaran setiap manusia terhadap hak-hak orang lain dan kewajiban dirinya, Jika ia berkewajiban melakukan sesuatu, ia berhak menerima sesuatu. Keduanya harus berjalan seimbang dan dirasakan adil untuk dirinya dan orang lain.

7. Prinsip Kemaslahatan, yaitu bertitik tolak dari kaidah penyusunan argumentasi dalam berperilaku, bahwa meninggalkan kerusakan lebih diutamakan daripada mengambil manfaatnya (dar'u al-mafasid muqadamun min jalb al-mashalahih).

\section{Pandangan Hukum Islam terhadap Jual Beli dalam E-Commerce}

Transaksi jual beli secara elektronik, sama halnya dengan transaksi jual beli biasa yang dilakukan di dunia nyata, dilakukan oleh para pihak yang terkait, walaupun dalam jual beli secara elektronik ini pihak-pihaknya tidak bertemu secara langsung satu sama lain, tetapi berhubungan melalui internet.

Pada dasarnya pihak-pihak dalam jual beli secara elektronik tersebut diatas, masing-masing memiliki hak dan kewajiban. Penjual/pelaku usaha/merchant merupakan pihak yang menawarkan produk melalui internet, oleh karena itu, seorang penjual wajib memberikan informasi secara benar dan jujur atas produk yang ditawarkannya kepada pembeli atau konsumen. Disamping itu, penjual juga harus menawarkan produk yang diperkenankan oleh undang-undang, maksudnya barang yang ditawarkan tersebut bukan barang yang bertentangan dengan peraturan perundang- undangan, tidak rusak ataupun mengandung cacat tersembunyi, sehingga barang yang ditawarkan adalah barang yang layak untuk diperjualbelikan. Dengan demikian transaksi jual beli termaksud tidak menimbulkan kerugian bagi siapapun yang menjadi pembelinya.
Jual beli secara elektronik pada kegiatan $e$-commerce menciptakan sebuah sistem ekonomi baru yang di dalamnya menghubungkan antara produsen, penjual, dan konsumen melalui sebuah teknologi yang tidak pernah dilakukan sebelumnya. Transaksi antar negara yang dilakukan via internet ini telah memunculkan pertanyaan bagi sebagian besar muslim mengenai kesesuaian transaksi ini dengan hukum dan aturan yang berlaku dengan syariat Islam, terutama dengan hukum jual-beli dalam muamalat maliyah. E-commerce yang tidak dilakukan dengan tatap muka (face to face) secara langsung antara penjual dan pembeli ini bertentangan dengan rukun dan syarat sah jual beli yang dikenal dengan literatur fiqh klasik.

Transaksi jual beli e-commerce, penawaran dilakukan oleh penjual atau pelaku usaha melalui website pada internet. Penjual atau pelaku usaha menyediakan storefront yang berisi katalog produk dan pelayanan yang akan diberikan. Masyarakat yang memasuki website pelaku usaha tersebut dapat melihat-lihat barang yang ditawarkan oleh penjual. Penawaran dalam sebuah website biasanya menampilkan barangbarang yang ditawarkan, harga, nilai rating atau poll otomatis tentang barang yang diisi oleh pembeli sebelumnya, spesifikasi barang termaksud dan menu produk lain yang berhubungan. e-commerce terjadinya penawaran apabila seseorang menggunakan media internet untuk berkomunikasi baik via email atau chating untuk memesan barang yang diinginkan.

Bila dilihat dari sistem operasionalnya, maka e-commerce menurut kacamata fikih kontemporer merupakan alat, media, metode teknis ataupun sarana (wasilah) yang dalam kaidah syari'ah bersifat flesibel, dinamis, dan variable. Hal ini termasuk unmurid dunya (persoalan teknis keduniawian) selama dalam koridor syari'ah kepada umat islam untuk menguasai dan memanfaatkan perkembangan zaman demi kemakmuran 
bersama. Menurut kaidah fikih sebagaimana dikemukakan oleh Wahbah Zuhaili bahwa prinsip dasar dalam transaksi muamalah dan persyaratannya yang terkait dengannya adalah boleh selama tidak dilarang oleh syari'ah atau bertentangan dengan dalil. Oleh karena itu, hukum transaksi dengan menggunakan media e-commerce adalah boleh berdasarkan prinsip maslahah karena akan kebutuhan manusia dengan kemajuan teknologi ini dengan berusaha memperbaiki dan menghindari kelemahan dan penyimpangan teknik dari syari'ah. Sebab tidak dapat dipungkiri bahwa mekanisme yang dibuat manusia tidak luput dari kelemahan dan selama masih relative aman dan didukung oleh upaya-upaya pengaman hal itu dapat ditolelir berdasarkan prinsip toleransi syariah dalam muamalah dan kaidah fiqih: adh-dhararu yuzal mudarat harus dihilangkan. Dan jual beli tersebut harus sah menurut syarat dan rukun syari'ah Islam, jika tidak maka jual beli yang rusak atau batal akan menghalangi kepemilikan, sebab larangan tersebut berarti tidak boleh menurut syara' maka sesuatu yang illegal (ghairu al-masyru') tidak dapat dimiliki oleh pembeli.

Berdasarkan tuntunan ajaran Islam, setiap usaha harus dilakukan menurut ketentuan hukum yang berlaku agar tidak ada kelompok atau pihak yang dirugikan. Untuk itulah, usaha atau kegiatan bisnis tidak boleh menyimpang dari syariat Islam maupun ketentuan umum yang berlaku dalam suatu negara. Setiap usaha yang merugikan seseorang atau melanggar undang-undang akan dikenakan sanksi, sedangkan dalam Islam transaksi dianggap batal (tidak sah). ${ }^{14}$

\footnotetext{
${ }^{14}$ Lihat Ali Hasan, Manajemen Bisnis Syariah: Kaya di Dunia Terhormat di Akhirat, Yogyakarta: Pustaka Pelajar, 2009, dalam Muhammad Zarkasyi, Perdagangan Elektronik E-Commerce dalam Perspektif Hukum Islam,

https://informasicoins.wordpress.com/2016/03/09/perdag angan-elektronik-e-commerce-dalam-perspektif-hukum-i slam/,
}

Ada lima tahap yang harus dilakukan untuk mengetahui validitas transaksi e-commerce, yaitu: ${ }^{15}$

1. Mengajukan kontrak (at-ta'aqud)

Ini adalah tahap pertama yang harus dilakukan dimana kedua belah pihak mengecek adanya empat pillar yang mengikat kontrak, yaitu: sighat (ijab qabul), dua pihak yang melakukan transaksi, barang yang diperjualbelikan, dan ungkapan yang harus disepakati. Jika pemilik produk tidak bisa hadir, maka seorang agen harus memastikan bahwa perusahaan tersebut benar-benar ada. Sehubungan dengan barang yang menjadi objek transaksi, selain syarat yang berlaku pada objek pada umumnya, dalam e-commerce, dimana transasksi dilakukan cia internet, maka barang tersebut harus tersedia di suatu tempat di pasar global.

\section{Memastikan validitas (shiha)}

Selama proses validitas, kontrak tersebut harus bebas dari elemen bunga (riba), ketidak pastian (gharar), penipuan, pemaksaan, atau salah satu dari jenis perjudian (maisir).

3. Implementasi/ pelaksanaan ( $\mathrm{Nafadz}$ )

Dalam tahap ini, ada dua hal utama yang harus dilakukan: orang yang menawarkan produk adalah pemilik produk itu sebenarnya dan memiliki hak penuh terhadap barang tersebut. Barang tersebut terbebas dari semua hutang-piutang dan mengikat (Ilzaam). Dalam tahap ini, kedua pihak harus menandatangani kontrak yang mengikat. Sebelum menandatangani kontrak, pembeli harus memeriksa perusahaan (penjual) dan produk yang dijual melalui agen atau pihak lain. Hal ini dilakukan karena konseumen tidak bisa melihat secara langsung kondisi barang, dan website bisa selalu dikembangkan.

\footnotetext{
15 Lihat Norazlina Zainul et-al, E-Commerce from an Islamic perspective, dalam Muhammad Zarkasyi, Perdagangan Elektronik E-Commerce dalam Perspektif Hukum Islam,

https://informasicoins.wordpress.com/2016/03/09/perdag angan-elektronik-e-commerce-dalam-perspektif-hukum-i $\underline{\text { slam/, }}$
} 
Setelah menandatangani kontrak, pembeli harus menyimpan copy dari kontrak tersebut untuk menghindari manipulasi.

\section{Pengiriman}

Tahapan Ini adalah tahapan dimana kedua pihak harus saling menukar antara barang dan harga yang harus dibayarkan. Pada umumnya, e-commerce menggunakan kartu kredit, namun muslim harus menghindari pemakaian kartu kredit yang mengandung riba, dan mencari alternatif pembayaran yang lain, seperti pembayaran melalui bank. Setelah menerima produk, konsumen juga harus memeriksa dan mengkonfirmasikan apakah barang yang diterima sesuai dengan kondisi dan spesifikasi yang disepakati. Dalam Islam, ada beberapa opsi yang dilakukan jika hal ini terjadi, yaitu dengan khiyar.

5. Pembayaran untuk transaksi
e-commerce

Pembayaran e-commerce pada umumnya dengan kartu kredit. Dalam Islam, jika diasumsikan bahwa penggunaan kartu kredit adalah halal, maka pembeli harus membayar harga secara keseluruhan sebelum tanggal yang ditentukan. Bagaimanapun, masalah utama dalam keabsahan $e$-commerce menurut pandangan Islam adalah dimana konsumen hanya membayar $15 \%$ dari syarat minimum, smeentara bank yang mengeluarkan akan menagih sebesar 2\% setiap bulan dari neraca yang ada. Untuk itulah, solusi dari Islam adalah murabahah.

Transaksi e-commerce yang dilakukan via internet, tanpa tatap muka secara langsung antara penjual dan pembeli menjadi permasalahan pada kesesuaian dan keshahihan akadnya menurut perspektif fiqih muamalat. Dari penelurusan terhadap beberapa literatur mengenai mekanisme akad dan pembayaran, maka transaksi e-commerce dianggap sesuai dengan akad jual beli yang umum dalam syariat Islam. Hal ini dipertegas oleh pendapat para ulama kontemporer dalam Majmu' Fatawa bahwa transaksi e-commerce tidak menyalahi syariat selama tidak merugikan salah satu pihak dan memenuhi rukun dan syarat sah jual beli dalam Islam. ${ }^{16}$

Asal dari setiap kegiatan muamalat adalah mubah (diperbolehkan), hingga ada hal yang mengubahnya. Dalam hal ini, baik transaksi e-commerce maupun jual beli tradisional tidak dilarang sesuai dengan firman Allah dalam Al Quran Surat Al-Jumuah ayat 10 yang artinya "Apabila telah ditunaikan shalat, maka bertebaranlah kamu di muka bumi; dan carilah karunia Allah dan ingatlah Allah banyak-banyak supaya kamu beruntung". Berdasarkan Tafsir Al-Wajiz oleh Prof. Dr. Wahbah az-Zuhail, maka jika selesai kalian dari mengerjakan shalat wahai orang-orang yang beriman; bertebaranlah di muka bumi untuk berikhtiar dan berdagang, dan carilah rezeki Allah dengan usaha dan amal, dan ingatlah Allah dengan banyak berdzikir pada segala kondisi kalian dan janganlah perdaganganmu melalikan dari dzikir kepada Allah, dan barangsiapa yang banyak mengingat Allah maka dia adalah orang-orang yang beruntung, menang dengan kemenangan yang besar. ${ }^{17}$

Meskipun tidak dilakukan secara langsung, namun dengan mekanisme dan deskripsi yang rinci serta seluruh kesepakatan yang telah disetujui kedua belah pihak maka dalam hal ini internet bisa dianggap sebagai majelis dimana penjual dan pembeli bertemu dan melaksanakan akad. Mengenai sighat, meskipun tidak dilakukan secara verbal (lisan), namun kesepakatan pembeli dengan meng-klik 'accept' bisa dianggap sebagai qabul dan dianggap sah sesuai dengan Ijma.

\section{Penutup}

Transaksi dalam e-commerce merupakan satu rangkaian yang dinamis pada teknologi, aplikasi dan proses bisnis yang menghubungkan perusahaan, konsumen dan komunitas tertentu melalui

\footnotetext{
16 Ibid

17 https://tafsirweb.com/10910- surat-al-jumuah -ayat-10 .html
}

Volume 17 Nomor 1. Bulan Januari 2019 
transaksi elektronik dan perdagangan barang, pelayanan dan informasi yang dilakukan secara elektronik.

Pandangan Hukum Islam pada jual beli e-commerce adalah boleh, jika sesuai dengan kaidah fikih dalam prinsip dasar transaksi muamalah dan persyaratannya selama tidak dilarang oleh syariah atau bertentangan dengan dalil. Oleh karena itu, hukum transaksi dengan menggunakan media e-commerce adalah boleh berdasarkan prinsip maslahah dalam rangka pemenuhan kebutuhan manusia dengan memanfaatkan perkembangan dan kemajuan teknologi. Kegiatan e-commerce harus sesuai syariah dengan cara menghindari penyimpangan-penyimpangan secara teknis.

\section{DAFTAR PUSTAKA}

Ali Hasan, Manajemen Bisnis Syariah: Kaya di Dunia Terhormat di Akhirat, Yogyakarta: Pustaka Pelajar, 2009.

Azhar Muttaqin, Transaksi E-Commerce dalam Tinjauan Hukum Jual Beli Islam, ULUMUDDIN, Volume VI, Tahun IV, Januari - Juni 2010.

Beni Ahmad Saebani, Filsafat Hukum Islam, Bandung: Pustaka Setia, 2008.

Edmon Makarim, Kompilasi Hukum Telematika. Jakarta: PT.Gravindo Persada, 2000.
Elsi Kartika Sari dan Advendi Simanunsong, Hukum dalam Ekonomi, Jakarta: PT Gramedia Widiasarana Indonesia, 2008.

Jamhurul dalam Muhammad Nizar, Pendekatan Komprehensif E-Commerce Prespektif Syariah, Perisai, Vol 2 (1), April 2018.

Juhaya S. Pradja, Filsafat Hukum Islam, Bandung: Yayasan Piara, 1997.

Munir Fuady, Pengantar Hukum Bisnis, Menata Bisnis Modern di Era Global, Bandung: PT Citra Aditya Bakti, 2008

Muhammad Zarkasyi, Perdagangan Elektronik E-Commerce dalam Perspektif Hukum Islam,

https://informasicoins.wordpress.co $\mathrm{m} / 2016 / 03 / 09 /$ perdagangan-elektroni k-e-commerce-dalam-perspektif-huk um-islam/,

https://www.kajianpustaka.com/2013/04/perda gangan-elektronik-e-commerce.html,

https://dalamislam.com/hukum-islam/ekonomi/ jual-beli-menurut-islam

https://muslim.or.id/222-jual-beli-dan-syarat-sy aratnya.html

https://tafsirweb.com/10910-surat-al-jumuah-a yat-10.html 